\title{
Hydrology and water resources management in ancient India
}

\author{
Pushpendra Kumar Singh ${ }^{1}$, Pankaj Dey ${ }^{2}$, Sharad Kumar Jain ${ }^{\text {a }}$, and Pradeep P. Mujumdar ${ }^{2,3}$ \\ ${ }^{1}$ Water Resources Systems Division, National Institute of Hydrology, Roorkee, 247667, India \\ ${ }^{2}$ Department of Civil Engineering, Indian Institute of Science, Bengaluru, 560012, India \\ ${ }^{3}$ Interdisciplinary Centre for Water Research, Indian Institute of Science, Bengaluru, 560012, India \\ ${ }^{\mathrm{a}}$ visiting professor at: Department of Civil Engineering, Indian Institute of Technology, Roorkee, 247667, India
}

Correspondence: P. P. Mujumdar (pradeep@iisc.ac.in)

Received: 5 May 2020 - Discussion started: 11 May 2020

Revised: 1 August 2020 - Accepted: 22 August 2020 - Published: 5 October 2020

\begin{abstract}
Hydrologic knowledge in India has a historical footprint extending over several millenniums through the Harappan civilization ( 3000-1500 BCE) and the Vedic Period $(\sim 1500-500 \mathrm{BCE})$. As in other ancient civilizations across the world, the need to manage water propelled the growth of hydrologic science in ancient India. Most of the ancient hydrologic knowledge, however, has remained hidden and unfamiliar to the world at large until the recent times. In this paper, we provide some fascinating glimpses into the hydrological, hydraulic, and related engineering knowledge that existed in ancient India, as discussed in contemporary literature and revealed by the recent explorations and findings. The Vedas, particularly, the Rigveda, Yajurveda, and Atharvaveda, have many references to the water cycle and associated processes, including water quality, hydraulic machines, hydro-structures, and nature-based solutions (NBS) for water management. The Harappan civilization epitomizes the level of development of water sciences in ancient India that includes construction of sophisticated hydraulic structures, wastewater disposal systems based on centralized and decentralized concepts, and methods for wastewater treatment. The Mauryan Empire ( 322-185 BCE) is credited as the first "hydraulic civilization" and is characterized by the construction of dams with spillways, reservoirs, and channels equipped with spillways (Pynes and Ahars); they also had an understanding of water balance, development of water pricing systems, measurement of rainfall, and knowledge of the various hydrological processes. As we investigate deeper into the references to hydrologic works in ancient Indian literature including the mythology, many fascinating dimensions of the Indian scientific contributions emerge. This review presents the various facets of water management, exploring
\end{abstract}

disciplines such as history, archeology, hydrology and hydraulic engineering, and culture and covering the geographical area of the entire Indian subcontinent to the east of the Indus River. The review covers the period from the Mature Harappan Phase to the Vedic Period and the Mauryan Empire.

\section{Introduction}

Water is intimately linked to human existence and is the source of societal and cultural development, traditions, rituals, and religious beliefs. Humans created permanent settlements about 10000 years ago when they adopted an agrarian way of life and began developing different sociocultural societies and settlements, which were largely dependent on water in one way or another (Vuorinen et al., 2007). These developments established a unique relationship between humans and water. Most of the ancient civilizations, e.g., the Indus Valley, Egyptian, Mesopotamian, and Chinese, developed at places where water required for agricultural and human needs was readily available, i.e., in the vicinity of springs, lakes, rivers, and seas (Yannopoulos et al., 2015). As water was the prime mover of the ancient civilizations, a clear understanding of the hydrologic cycle, nature, and patterns of its various components along with water uses for different purposes led those civilizations to flourish for thousands of years.

The Harappan (or Indus Valley) civilization $(\sim 3000$ $1500 \mathrm{BCE})$, one of the earliest and most advanced civilizations of the ancient times, was also the world's largest in spatial extent and epitomizes the level of development of science and society in the protohistoric Indian subcontinent. The 
Harappan civilization did not have the "single state" concept as was practiced by the other contemporary civilizations such as the Mesopotamian civilization, pointing to evidence of centralized control of palaces and temples and differentiated burials (Kenoyer, 1994; Possehl, 1998, 2003). The Harappan society was based on shared concepts of power; dominance and patterns of military conquests have not been found in this society (Kenoyer, 2003). However, more information will be revealed to the world once the linguists decipher the Harappan script inscribed on the seals, amulets, and pottery vessels (Kenoyer, 2003). Jansen (1989) states that the citizens of the Harappan civilization were known for their obsession with water; they prayed to the rivers every day and accorded the rivers a divine status. The urban centers were developed with state-of-the-art civil and architectural designs with provisions for sophisticated drainage and wastewater management systems. It is interesting to note in this context that the water and wastewater management systems have been highly amenable to the sociocultural and socioeconomic conditions and religious ways of societies through all the ages of the civilizations (Sorcinelli, 1998; Wolfe, 1999; De Feo and Napoli, 2007; Lofrano and Brown, 2010).

Agriculture was the main economic activity of the Harappan society and an extensive network of reservoirs, wells, canals as well as low-cost water-harvesting techniques were developed throughout the region at that time (Nair, 2004). Mohenjo-Daro and Dholavira, the two major cities of the Indus Valley, are the best examples of advanced water management and drainage systems. The Great Bath of MohenjoDaro of the Indus Valley is considered the "earliest public water tank of the ancient world" (Mujumdar and Jain, 2018). Adequate archeological evidence exists to testify that the Harappans of the Indus Valley were well aware of the seasonal rainfall and flooding of the Indus River during the period between 2500 and $1700 \mathrm{BCE}$, which is corroborated by modern meteorological investigations (Srinivasan, 1976).

Following the de-urbanization phase ( 1900-1500 BCE) of the Harappan civilization, the Vedic Period in the Indian subcontinent can be bracketed between $\sim 1500$ and 500 BCE. The "Rigveda" (the earliest of the four Vedas) as well as many other Vedic texts was composed in this period and in later periods (Kathayat et al., 2017; Witzel, 2014; Sen, 1999). The Vedic Period can be further classified into two stages as the "Early Vedic Period" ( 1500-1100 BCE) and the "Late Vedic Period" ( 1100-500 BCE) (Kathayat et al., 2017; Witzel, 1987, 1999). During the Late Vedic Period, agriculture, metallurgy, commodity production, and trade were largely expanded (Kathayat et al., 2017); after the Late Vedic Period the period of "Mahājanapadas" came into existence, which finally converged into the "Mauryan Empire". The Vedic texts contain valuable references to the hydrological cycle. It was known during Vedic and later times (Rigveda, VIII, 6.19; VIII, 6.20; and VIII, 12.3) (Sarasvati, 2009) that water is not lost in the various processes of the hydrological cycle, namely, evaporation, condensation, rain- fall, streamflow, etc., but gets converted from one form to another. At that time Indians were acquainted with cyclonic and orographic effects on rainfall (Vayu Purana) and radiation, as well as convectional heating of the Earth and evapotranspiration. The Vedic texts and other Mauryan period texts such as Arthashastra mention other hydrologic processes such as infiltration, interception, streamflow, and geomorphology, including the erosion process. Reference to the hydrologic cycle and artesian wells is available in $R a$ mayana ( 200 BCE) (Goswami, 1973). Groundwater development and water quality considerations also received sufficient attention in ancient India, as evident from the Brihat Samhita (550 AD) (Jha, 1988). Topics such as water uptake by plants, evaporation, and clouds and their characteristics, along with rainfall prediction by observing the natural phenomena of previous years, had been discussed in Brihat Samhita (550 AD), Meghamala (900 AD), and other literature from ancient India.

The Arthashastra, attributed to Kautilya "who reportedly was the chief minister to the emperor Chandragupta (300 BCE), the founder of the Mauryan dynasty" (Encyclopaedia Britannica, https://www.britannica.com/topic/ Artha-shastra, last access: 27 April 2020), deals with several issues of governance, including water governance. It mentions a manually operated cooling device referred to as "Variyantra" (revolving water spray for cooling the air). The Variyantra was similar to the water cooler. According to Megasthenes (an ancient Greek historian, who visited the court of king Chandragupta Maurya around $300 \mathrm{BCE})$, the Variyantra was used by the wealthier sections of the society for cooling the air. The Arthashastra also gives an extensive account of hydraulic structures built for irrigation and other purposes during the period of the Mauryan Empire (Shamasastry, 1961).

The Pynes and Ahars (combined irrigation and water management system), reservoir (Sudarshan lake) at Girnar, and many other structures were also built during the Mauryan Empire ( 322-185 BCE). McClellan III and Dorn (2015) noted that "the Mauryan Empire was first and foremost a great hydraulic civilization". This suggests that the technology of the construction of the dams, reservoirs, channels, measurement of rainfall, and knowledge of the various hydrological processes existed in the ancient Indian society. Megasthenes mentions that "more than half of the arable land was irrigated and was in agriculture and produced two harvests in a year". Further, there was a separate department for supervision, construction, and maintenance of a well-developed irrigation system with extensive canals and sluices, wells, lakes and tanks. The same bureau was responsible for planning and settlement of the uncultivated land. A similar description of the different institutional arrangements during the Mauryan period can be seen in Arthashastra. The importance of the hydraulic structures in the Mauryan period can be judged on the basis of the punishments or fines imposed on the offenders. As mentioned in the Arthashastra, 
"when a person breaks the dam of a tank full of water, he shall be drowned in the very tank; of a tank without water, he shall be punished with the highest amercement; and of a tank which is in ruins owing to neglect, he shall be punished with the middle-most amercement".

Remarkably, the Mauryan Empire did not lack the other hallmarks associated with the hydraulic civilizations (McClellan III and Dorn, 2015). It had departments concerned with the rivers, excavating, and irrigation along with a number of regional and other superintendents such as the superintendent of rivers; agriculture; weights and measures; store house; space and time; ferries, boats, and ships; towns; pasture grounds; road cess; and many others along with other strata of the associated officers such as head of the departments (adhyakshah), collector general (samahartri), and chamberlain (sannidhatri), etc. Olson (2009) also mentions that there was an extensive irrigation network organized by a state bureaucracy. According to Wittfogel (1955), the Mauryan Empire had virtually all of those characteristics that a hydraulic civilization must possess (though it was rather short lived).

Water pricing was also an important component of the water management system in the Mauryan Empire. According to Arthashastra, those who cultivate through irrigation (i) by manual labor (hastaprávartimam) would have to pay onefifth of the produce as water rate (udakabhágam); (ii) by carrying water on shoulders (skandhaprávartimam), one-fourth of the produce; (iii) by water lifts (srotoyantraprávartimam), one-third of the produce; and (iv) by raising water from rivers, lakes, tanks, and wells (nadisarastatákakúpodghátam), one-third or one-fourth of the produce. The superintendent of agriculture was responsible for compiling the meteorological statistics by using a rain gauge and for observing the sowing of the wet crops, winter crops or summer crops depending on the availability of the water.

Historical development of hydro-science has been dealt with by many researchers (Baker and Horton, 1936; Biswas, 1969; Chow, 1964). However, not many references to the hydrological contributions in ancient India are found. Chow (1974) rightly mentions that "the history of hydrology in Asia is fragmentary at best and much insight could be obtained by further study". According to Mujumdar and Jain (2018), there is rigorous discussion in ancient Indian literature on several aspects of hydrologic processes and water resources development and management practices as we understand them today.

Evidence from ancient water history provides an insight into the hydrological knowledge generated by Indians more than 3000 years ago. This paper explores many facets of ancient Indian knowledge on hydrology and water resources with a focus on hydrological processes, measurement of precipitation, water management and technology, and wastewater management, which are based on reviews of the Indian scriptures, such as the Vedas, Arthashastra (Shamasastry, 1961), Astadhyayi (Jigyasu, 1979), Ramayana (Goswami,
1973), Mahabharata; Puranas, Brihat Samhita (Jha, 1988), Meghamala, Mayurchitraka; Jainist and Buddhist texts; and other ancient texts. In this review, we present a glimpse of the knowledge that existed in ancient India in water sciences by exploring many disciplines such as history, archeology, hydrology, and hydraulic engineering, history of technology and history of culture. The paper follows the order based on process or technology. While doing so, the historical order of those processes or technologies has also been followed in each section. The review covers the geographical area of the entire Indian subcontinent to the east of the Indus River. Specifically, it includes the parts of the Harappan civilization (in present-day Pakistan) and the whole of India with historical boundaries from the Mature Harappan Phase to the Mauryan Empire. These boundaries encompass the major centers or regions of development in ancient India, and the Mauryan Empire is considered the terminal point of ancient India, which is also consistent with the views of Olson (2009) that the Mauryan Empire can be considered the historical boundary of ancient India.

\section{Knowledge of hydrological processes in ancient India}

The hydrologic cycle is the most fundamental concept in hydrology that involves the entire Earth system comprising the atmosphere (the gaseous envelop), the hydrosphere (surface and subsurface water), lithosphere (soils and rocks), the biosphere (plants and animals), and the oceans. Water passes through these five spheres of the Earth system in one or more of the three phases: solid (ice), liquid, and vapor. The Rigveda, which is an ancient religious scripture, contains many references to the hydrologic cycle and associated processes (Sarasvati, 2009). The Rigveda mentions that "the God has created Sun and placed it in such a position that it illuminates the whole universe and extracts water continuously (in the form of vapor) and then converts it to cloud and ultimately discharges as rain" (verse I, 7.3). Many other verses of the Rigveda (I, 19.7; I, 23.17; I, 32.9) further explain the transfer of water from the Earth to the atmosphere by the Sun and wind; breaking up of water into small particles, evaporation due to Sun rays, and subsequent rain; and formation of cloud due to evaporation of water from Mother Earth and returning in the form of rain. Verse I, 32.10, of the Rigveda further mentions that the water is never stationary but it continuously gets evaporated, and due to smallness of particles we cannot see the evaporated water particles. According to Atharvaveda also ( 1200-1000 BCE), the Sun rays are the main cause of rain and evaporation (verse I, 5.2, in Sanskrit language):

$$
\begin{aligned}
& \text { amurya up surye yabhirg suryah sah|ta no } \\
& \text { hinvantvadhavaram|| }
\end{aligned}
$$

The Yajurveda ( 1200-1000 BCE) explains the process of water movement from clouds to Earth and its flow through 
channels and storage into oceans and further evaporation (verse X, 19). During the time of Atharvaveda, the concepts of water evaporation, condensation, rainfall, river flow and storage, and again repetition of the cycle were also well known as in the earlier Vedas. Therefore, it can be inferred that, during the Vedic and earlier periods in India, the concepts of infiltration, water movement, storage, and evaporation as part of the hydrologic cycle were well known to the contemporary Indian scholars.

The epic Mahabharata (verse XII, 184.15-16) explains the water uptake process by plants and mentions that rainfall occurs in 4 months (the Indian summer monsoon, ISM) (verse XII, 362.4-5); in the next 8 months (non-monsoon months), the same water is extracted by the Sun rays through the process of evaporation. Likewise, in other Indian mythological scriptures such as Puranas (which are dated probably between $600 \mathrm{BCE}$ and $700 \mathrm{AD}$ ), numerous references to hydrological cycle can be found (NIH, 2018). The Matsya Purana (verse I, 54.29-34) and Vayu Purana (verse 51.2326) mention the evaporation process which burns water by Sun rays and which is converted to vapor (i.e., the process of evaporation). These vapors ascend to the atmosphere with the help of air and fall as rain in the next rainy season for the goodness of the living beings (NIH, 2018). The Vayu Purana and the Matsya Purana also mention the rainfall potential of clouds and the formation of clouds by cyclonic, convectional, and orographic effects (Nair, 2004). Similarly, the Linga Purana (verse I, 36.67) clearly explains the various processes of the hydrologic cycle such as evaporation, and condensation and mentions that water cannot be destroyed; it gets changed from one form to another (NIH, 2018; Sharma and Shruthi, 2017) as the following.

jalasya nasho vridwirva natatyevasya vichartah|ghravenashrishthto vayuvrishti sanhrte punah||

The Brahmanda Purana (verse II, 9.138-139; 167-168) explains that the Sun has rays of seven colors which extract water from all sources through heating (evaporation), and it gives to the formation of clouds of different colors and shapes and finally these clouds rain with high intensity and great noise (NIH, 2018). The Vayu Purana also refers to the various underground structures and topography such as lakes, barren tracts, dales, and rocky rift valleys between mountains (verse 38.36).

The Kishkindha sarga (chap. 28; verses: 03, 07, 22, 27, 46) of the epic Ramayana discusses various aspects of the hydrological cycle. Verse 3 mentions the formation of clouds by Sun and wind (through the process of evaporation from the sea) and raining the elixir of life (water), and verse 46 mentions the overflowing of the rivers due to heavy rains in the rainy season. Verse 22 explains the process of cloud transportation laden with water and elevational effects of the mountains on the whole process. Based on these verses (and many more not mentioned here), a depiction on the various stages of the hydrologic cycle may also be established similar to Horton (1931). Malik (2016) also compared the various concepts of the modern hydrologic cycle with those presented in the Ramayana and found that a corollary may be established between them.

The Brihat Samhita (literally meaning big collection) (550 AD) by Varahamihira contains many scientific discourses on the various aspects of meteorology, e.g., "pregnancy" of clouds, pregnancy of air, winds, cloud formations, earthquakes, rainbows, dust storms, and thunder bolts among other things such as colors of the sky, shapes of clouds, the growth of vegetation, behavior of animals, the nature of lightning and thunder, and associated rainfall patterns (Jha, 1988). The water falling from the sky assumes various colors and tastes from differences in the nature of Earth. Out of 33 chapters in the Brihat Samhita, 10 chapters are specifically devoted to meteorology. This highlights the depth of the meteorological knowledge prevalent during the period of Varahamihira and his predecessors in ancient India.

Verse 54.104 of Brihat Samhita explains the relation between soil and water. It is mentioned that pebbly and sandy soil of copper color makes water astringent. Brown-colored soil gives rise to alkaline water, yellowish soil makes water briny, and in blue soil underground water becomes pure and fresh. Brihat Samhita also discusses about the geographical pointers such as plants, reptiles, and insects as well as soil markers to gauge the groundwater resources (occurrence and distribution) (chap. 55, "Dakargalam"). It explains groundwater recharge as "the water veins beneath the earth are like vein's in the human body, some higher and some lower" as given in the following verses (NIH, 2018):

Dharmyam yashashyam va vadabhaytoham dakargalam yen jaloplabdhiha Punsam yathagdeshu shirastathaiva chhitavapi pronnatnimnasanstha.

Ekayna vardayna rasayna chambhyashchyutam namasto vasudha vishayshanta Nana rastvam bahuvarnatam cha gatam pareekshyam chhititulyamayva.

The Dakargalam (Brihat Samhita, chap. 55) deals with groundwater exploration and exploitation with various surface features, which are used as bioindicators to locate sources of groundwater, at depths varying from $2.29 \mathrm{~m}$ to as much as $171.45 \mathrm{~m}$ (Prasad, 1980). The bioindicators, described in this ancient Sanskrit work, include various plant species, their morphologic and physiographic features, termite mounds, geophysical characteristics, soils, and rocks (Prasad, 1986). All these indicators are nothing but the conspicuous responses to biological and geological materials in a microenvironment, consequential to high relative humidity in a groundwater ecosystem, developed in an arid or semiarid region. Variation in the height of the water table with place, hot and cold springs, and groundwater utilization by means of wells, along with well construction methods and 
equipment, are fully described in the Dakargalam (Jain et al., 2007). It also means that the water which falls from the sky originally has the same color and same taste but assumes different color and taste after falling on the surface of the Earth and after percolation. There are also mentions of the plant species and/or stone pitching in details for bank protection of water channels in Brihat Samhita.

Glucklich (2008) opines about the Brihat Samhita: "as the name of the work itself indicates, its data came from numerous sources, some of them probably quite old. However, the prestige and systematic nature of the Brihat Samhita gave its material the authority of prescriptions". Further, it is also appropriate to quote Varahamihira (chap. 1, verse II, Brihat Samhita) that "having correctly examined the substance of the voluminous works of the sages of the past, I attempt to write a clear treatise neither too long nor too short" (Iyer, 1884). Here, it would be appropriate to recollect words of Murty (1987) that Varahamihira could be considered the "earliest hydrologist" of the contemporary world in the same vein as Leonardo da Vinci being considered the "Master of Water".

An interesting fact covered in detail by Varahamihira is the role of termite knolls as an indicator of underground water. Apart from underground water exploration, some of the verses of the chapter deal with topics such as digging of wells; their alignment with reference to the prevailing winds; dealing with hard refractory stony strata; sharpening and tempering of stone-breaking chisels and their heat treatment; treating water with herbs when having an objectionable taste or smell; protection of banks with timbering, stoning, and planting with trees; and such other related matters.

The Jainist literature also made considerable contributions in the field of meteorology. The "Prajnapana" and "Avasyaka Curnis" provide outstanding references to the various types of winds (Tripathi, 1969). The Avasyaka Curnis furnishes a list of 15 types of winds, and the Prajnapana also mentions snowfall and hailstorms as forms of precipitation. The Buddhist literature also throws significant light on meteorology. In the narrative of the first Jataka, named "Apannaka", several climatological facts are described therein. The Buddhist literature refers to two general classes of clouds: monsoon cloud and storm clouds or accidental ones (Tripathi, 1969). The Samyutta Nikaya classifies clouds into five categories as (i) cool clouds, (ii) hot clouds, (iii) thunder clouds, (iv) wind clouds - formed due to the activity of convection current in the atmosphere, and (v) rain clouds - most probably cumulonimbus, which brings copious downpours of rain.

\section{Measurement of precipitation}

The Arthashastra and Astadhyayi of Panini (700 BCE) mention the rain gauges (Nair, 2004), which were introduced by the Mauryan rulers in the Magadha country (south Bihar) in the fourth or third century BCE. They are also credited with the establishment of the first observatory. The system continued to be used by the succeeding rulers until the end of the sixth century AD (Srinivasan, 1976). During the Mauryan period, the rain gauge was known as "Varshamaan". In the Arthashastra, the construction of the rain gauge is described as "in front of the store house, a bowel (Kunda) with its mouth as wide as an aratni (24 angulas $=18$ in. nearly) shall be set up as rain gauge". However, the Arthashastra does not have any information about the height of the rain gauge (Srinivasan, 1976). This rain gauge continued to be employed effectively by the succeeding rulers until the end of 600 AD (Srinivasan, 1976; Murty, 1987).

The distribution of rainfall in various regions was well known during the Mauryan period. The Arthashastra mentions the following (Shamasastry, 1961):

The quantity of rain that falls in the country of jangala (desert regions) is 16 dronas; half as much more in anupanam (moist regions); as the regions which are fit for agriculture (desavapanam); 13.5 dronas in the regions of asmakas (Maharashtra); 23 dronas in Avanti (probably Malwa); and an immense quantity in aparantanam (western regions, the area of Konkan); the borders of Himalayas and the countries where water channels are made for use in agriculture.

Kautilya's method of classification of rainfall areas in relation to the annual average quantity is indeed remarkable and he is the only classical author who treats this aspect in a nutshell covering almost the whole of the Indian subcontinent (Srinivasan, 1976). From this, it is evident that the methodology of measurement of rainfall given in Arthashastra is the same as we have today; the only difference is that rain was expressed in weight units. Discussing the further geographical details of rainfall variation, it is mentioned therein that "when one-third of the requisite quantity of the rainfall, during both the commencement and closing months of the rainy season, and two-third in the middle, then the rainfall is considered very even".

The science of forecasting the rains had also come into existence as (and must have been) developing empirically. It is further mentioned in the Arthashastra that "the rainfall forecasting can be made by observing the position, motion and pregnancy (garbhadhan) of Jupiter (Brihaspati), the rising, setting, and motion of Venus; and the natural or unnatural aspects of the Sun. From the movement of Venus, rainfall can be inferred". Detailed descriptions on the classification of clouds and their water holding capacity (equivalent to the concept of atmospheric rivers) and the interrelationship of rainfall patterns and agriculture can also be found in the Arthashastra.

Therefore, it can be concluded that during the Vedic era and afterwards in the age of epics and Puranas (i.e., from $3000 \mathrm{BCE}$ to $500 \mathrm{AD}$ ), knowledge of the hydrologic cycle, 
groundwater, and water quality was highly advanced, although the people of those times were solely dependent upon their experience of nature, without the sophisticated instruments of modern times. In the Vedic age, Indians had developed the concept that water gets divided into minute particles due to the effect of Sun rays and wind, which ascends to the atmosphere by the air column (the invisible drains); there, it gets condensed and subsequently falls as rainfall (Vayu Purana, 51.14-16). The Linga Purana also details the various aspects of the hydrological cycle (Sharma and Shruthi, 2017). Monthwise change in the facets of the hydrological cycle was also known. Water uptake by plants, which is facilitated by the conjunction of air along with the knowledge of infiltration, is revealed in the ancient literature. In Brihat Samhita, a full chapter is devoted to the formation of clouds (Garbhalakshanam). A detail discussion has been given on the properties of rainy seasons and their relationship with the movement of the planets and cloud formations (Murty, 1987). The Brihat Samhita also discusses the measurement of rainfall and the dimensions of the rain gauge (Murty, 1987).

During the Mauryan period, it was possible to describe the distribution of rainfall in different areas of India. Mauryans are credited with the installation of the first observatory worldwide (Srinivasan, 1976). Modern meteorological facts like the arid region of the Tibetan rain shadow area and no rainfall due to polar winds are extensively covered in $\mathrm{Pu}$ ranas. The Jainist and Buddhist works estimated the actual height of clouds. Knowledge of monsoon winds (Tripathi, 1969) and their effects as conceived by ancient Indians (Brihat Samhita) is in accordance with modern hydro-science. These facts show that there was enriched knowledge of water science and associated processes, including meteorology during ancient times in India, which is on par with modern water science.

Based on review of the work on water sciences from Mature Harappan Phase to the Mauryan period, it can be very well established that the ancient Indians were aware of cloud formation, rainfall prediction and its measurements, underground water-bearing structures, high and low water tables at different places, hot and cold springs, groundwater utilization by means of wells, well construction methods and equipment, underground water quality, and even the artesian well schemes. This shows that well-developed concepts of the hydrological cycle, groundwater, and water quality were known to the ancient Indians in those ancient times while the contemporary world was still struggling with unscientific ideas on the distribution of water (see e.g., Dooge, 2004).

\section{Water management technology in ancient India}

The development of sociocultural societies, agricultural establishments, and permanent settlements led to the establishment of a unique relationship between humans and wa- ter (Vuorinen et al., 2007; Lofrano and Brown, 2010). Scarborough (2003) and Ortloff (2009) discussed the impacts of water management practices on ancient social structures and organizations with examples from the eastern and western hemispheres. Lofrano and Brown (2010) presented an indepth review of wastewater management in the history of mankind, and they have categorically discussed about the evolution of sanitation through different civilizations of the world, including the ancient Indus Valley civilization.

As in many other parts of the world, civilization in India also flourished around rivers and deltas. Rivers remain an enduring symbol of national culture (Nair, 2004). The Harappan (or Indus Valley) civilization (Fig. 1), which prospered during 2600-1900 BCE (Chase et al., 2014) or about 5000 years ago (Dixit et al., 2018), had well-planned cities equipped with public and private baths, a well-planned network of sewerage systems through underground drains built with precisely laid bricks, and an efficient water management system with numerous reservoirs and wells (Sharma and Shruthi, 2017). Evidence shows that the Indus people developed one of the smartest urban centers in those ancient times with an exemplary fusion of civil, architectural, and material sciences (Possehl, 2002; Kenoyer, 1998; Wright, 2010). According to Shaw et al. (2007), the development of advanced irrigation systems in ancient India led to the development of the complex urban societies and centers. The Indus Valley civilization was prominent in hydraulic engineering and is known to have developed the earliest known systems of flush toilets in the world (Sharma and Shruthi, 2017). Kenoyer (2003) states that "no other city in the ancient world had developed such a sophisticated water and waste management system. Even during the Roman Empire, some 2000 years later, these kinds of facilities were limited to upper-class neighborhoods".

Dholavira, an important city in the Indus Valley civilization, contained sophisticated water management systems comprising series of reservoirs, step wells, and channels (Kirk, 1975; Sharma and Shruthi, 2017; Wright, 2010) (Fig. 2a and b). The city is ringed with a series of 16 large reservoirs ( $7 \mathrm{~m}$ deep and $79 \mathrm{~m}$ long), with some of them interconnected together; these storage structures account for about $10 \%$ of the area of the city (Iyer, 2019). The ability to conserve every drop of water in the parched landscape speaks volumes about the engineering skills of the people of Dholavira. Recently, a rectangular step well was found at Dholavira which measured $73.4 \mathrm{~m}$ long, $29.3 \mathrm{~m}$ wide, and $10 \mathrm{~m}$ deep, making it 3 times bigger than the Great Bath of Mohenjo-Daro (https://www.secret-bases.co. uk/wiki/Dholavira, last access: 28 April 2020).

The systems that Harappans of Dholavira city developed for conservation, harvesting, and storage of water speak eloquently about their advanced hydraulic engineering capabilities, given the state of technology (Baba et al., 2018). The "Lothal" (meaning "mound of the dead"), known as the harbor city of the Harappan civilization (Bindra, 2003), is lo- 


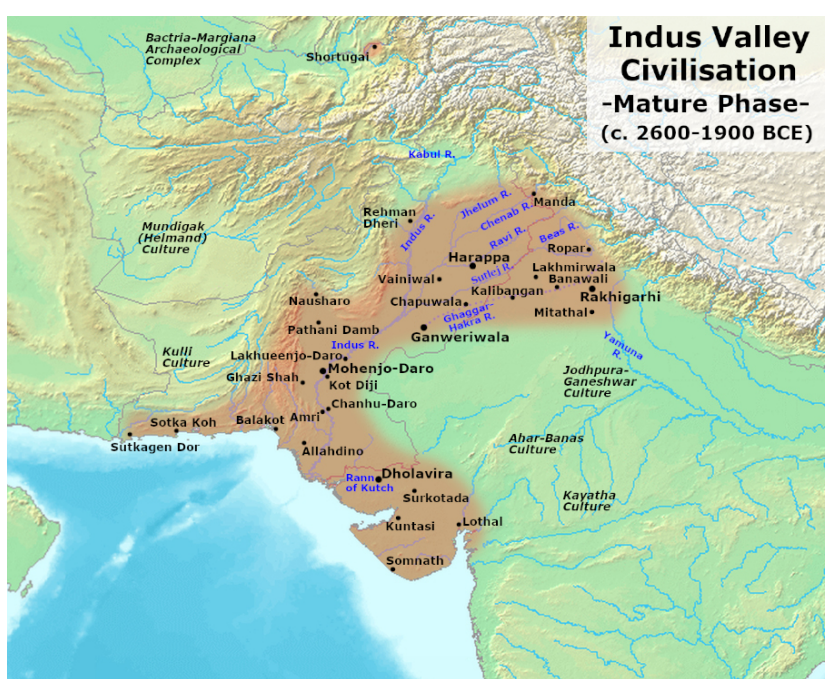

Figure 1. Geographical extent of the Indus Valley civilization (source: https://commons.wikimedia.org/wiki/File:Indus_Valley_ Civilization,_Mature_Phase_(2600-1900_BCE).png, last access: 23 August 2020).

cated at the doab of the Sabarmati and Bhogavo rivers. A roughly trapezoidal structure having dimensions of $212.40 \mathrm{~m}$ on the western embankment, $209.30 \mathrm{~m}$ on the eastern one, $34.70 \mathrm{~m}$ on the southern one, and $36.70 \mathrm{~m}$ on the northern one (Rao, 1979) at Lothal is an example of advanced maritime activities in those old days; and it is claimed by the archeologists to be the first known dockyard of the world (Nigam et al., 2016). Figure $3 \mathrm{a}$ and $\mathrm{b}$ show the dockyard at the Lothal after rains and the ancient Lothal as envisaged by the Archaeological Survey of India (ASI). According to Nigam et al. (2016), the existence of the massive protective wall (thickness of up to $18 \mathrm{~m}$ ) around the Dholavira city indicates that the ancient Indians were aware of oceanic calamities such as tsunami and storms.

Agriculture was practiced on a large scale having extensive networks of canals for irrigation (Nair, 2004). The irrigation systems, such as different types of wells, water storage systems and sustainable low-cost water-harvesting techniques, were developed throughout the region at that time (Nair, 2004; Wright, 2010). There is evidence that the Harappans constructed low-cost water-harvesting structures such as small check dams and bunds using rock-cut pieces and boulders. The Dholavira city was located between the ephemeral nullahs (streams) Mansar in the north and Manhar in the south (Fig. 4) and was equipped with a series of small check dams, stone drains for diverting water, and bunds to reduce the water velocity and thus to reduce siltation in the main reservoirs (eastern and western reservoirs) (Nigam et al., 2016; Agrawal et al., 2018). The Gabarbands were also in use in the Harappan civilization. Similarly, the AharPyne system (an excellent example of participatory irrigation management and rainwater harvesting in the Mauryan era) is an example of sustainable low-cost rainwater-harvesting structures. Mohenjo-Daro was one of the major urban centers of the Harappan civilization, receiving water from at least 700 wells and almost all houses had one private well (Angelakis and Zheng, 2015). The wells were designed as circular to Pipal (Ficus religiosa) leaf shaped (Khan, 2014). Canalizing flood waters through ditches for irrigating the Rabi crops (crops of the dry season) was also practiced at that time (Wright, 2010). The farmers of Harappa frequently used "contouring, bunding, terracing, benching, Gabarbands (dams), and canals" for water management (Mckean, 1985). The Gabarbands (stone-built dams for storing and controlling water) were also prevalent in these times for irrigating agricultural lands during the dry seasons (Rabi crops) (Wright, 2010). It may be noted that the Rabi irrigation was mainly spate irrigation throughout the Indus Valley civilization (Miller, 2006; Petrie et al., 2017; Petrie, 2019), and water was provided by canals and wells. In the Indus context, it has been argued that perennial and ephemeral water courses were exploited for flood inundation when present, and when not, the inhabitants relied on rainfall, small-scale irrigation, well and/or lift irrigation, and ponds to supply water (Miller, 2006, 2015; Petrie, 2019; Weber, 1991, Petrie and Bates, 2017) as well as the Ahar-Pyne system during the Mauryan era.

During the Vedic age, the principle of collecting water from hilly areas of undulating surface and carrying it through canals to distant areas was known (Bhattacharya, 2012). In the Rigveda, many verses indicate that agriculture can be progressed by use of water from wells and ponds (verse I, 23.18, and verse V, 32.2). Verse VIII, 3.10, mentions construction of artificial canals by (Ribhus or engineer) to irrigate desert areas. Verses VIII, 49.6, and X, 64.9, emphasize efficient use of water; i.e., the water obtained from different sources such as wells, rivers, rain, and from any other sources on the earth should be used efficiently, as it is a gift of nature, for the wellbeing of all. There are also references to irrigation by wells (verse X, 25), canals (word "kulya" in Rigveda) (verse X, 99), and digging of the canal (verse X, 75) in the Rigveda. In Mahâbhâsya of Patañjali (150 BCE) the word "kulya" is also used.

Interestingly, the Rigveda (verses X, 93.12, and X, 101.7) has a mention of "asma-cakra" (a wheel made of stones). Water was raised with help of the wheel in a pail using a leather strap. There is also a mention of "Ghatayantra" or "Udghatana" (a drum-shaped wheel) around which a pair of endless ropes with ghata (i.e., earthen pots) tied at equal distances. In Arabic literature, the water-lifting wheel is also known as "Noria". Yannopoulos et al. (2015) state that the ancient Indians had already developed water lifting and transportation devices. Further, according to Joseph Needham (https://www.machinerylubrication.com/ Read/1294/noria-history, last access: 28 April 2020), based on evidence documented in Indian texts dating from around 350 BCE, the "Noria" was developed in India around the fifth or fourth century BCE and the knowledge was transmitted to 

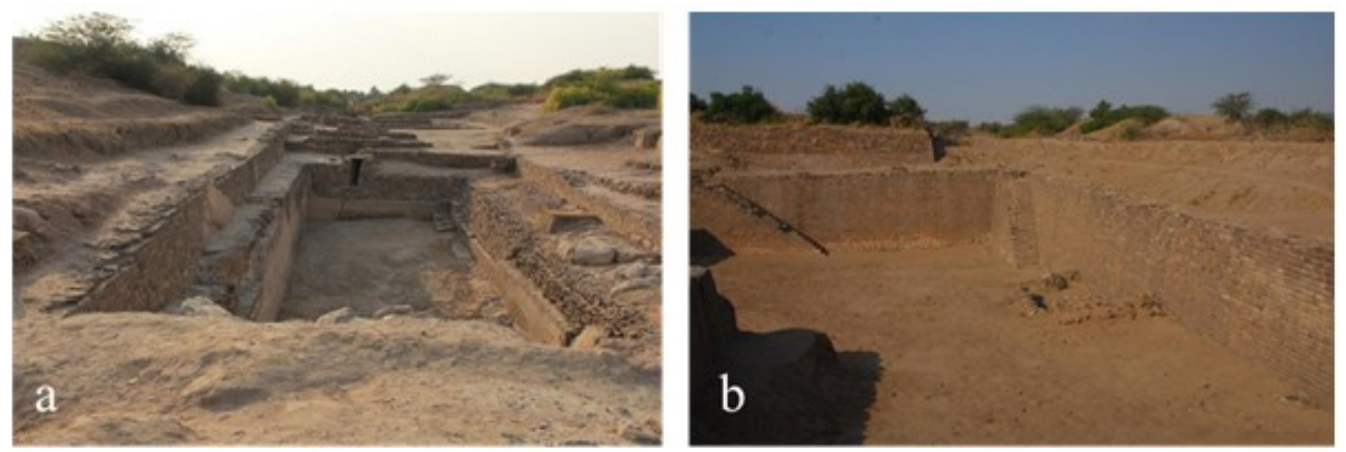

Figure 2. The southern (a) and eastern (b) reservoirs of Dholavira (source: Iyer, 2019).
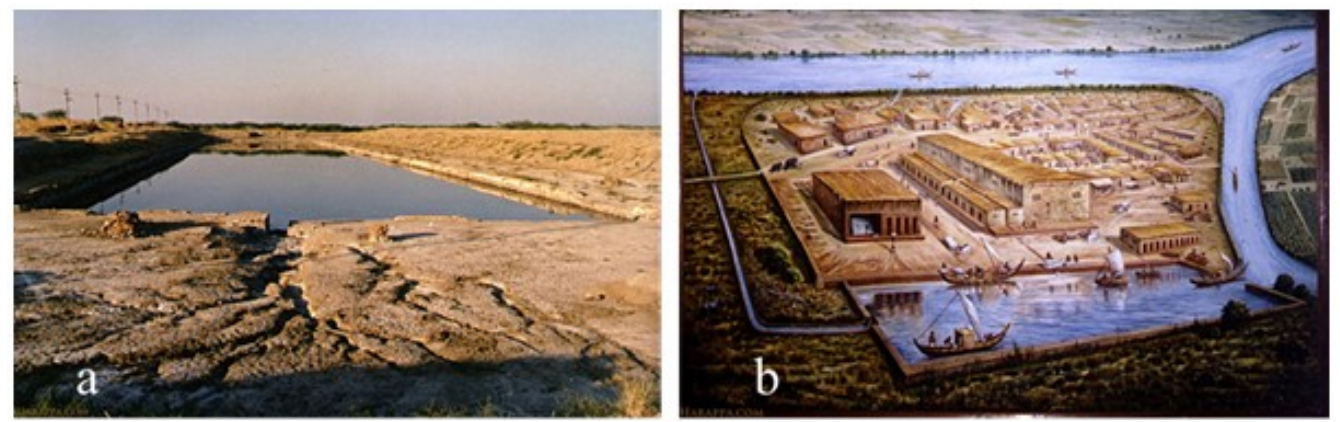

Figure 3. Dockyard (a) and ancient Indus port (b) of Lothal (source: https://www.harappa.com, last access: 27 April 2020).

the west by the first century $\mathrm{BCE}$ and to China by the second century $\mathrm{AD}$. It is worth mentioning here that during the Vedic Period, water for irrigation purposes was taken from lakes (hradah), canals (kulya), and wells. The exact meaning of the "asma-cakra" is "stone pully" or a "disk of stone". The buckets (kosa) tied with the strings made of leather (varatra) were pulled around a stone pulley and then emptied into the channels (Mukerji, 1960; Yadav, 2008). The Arthashastra also mentions irrigating the agricultural fields by raising water from rivers, lakes, tanks, and wells using a mechanical device known as "Udghatam" (Srinivasan, 1970).

Similar to Rigveda, Yajurveda also contains references to water management. Verses VI, 100.2, and VII, 11.1, of Yajurveda mention "that the learned men bring water to desert areas by means of well, pond, canals, etc., and the man should think about the drought and flood like natural calamities in advance and take preventive measures accordingly". Verse XII, 1.3, of Atharvaveda mentions that those who use rainwater by means of rivers, wells, and canals for navigation, recreation, agriculture, etc., prosper all the time. Similarly, verse XX, 77.8, of the Atharvaveda directs the king to construct suitable canals across mountains to provide water for his "subjects" for agriculture and other purposes. The Yajurveda also has references directing the man to use rain and river water by means of wells, ponds, and dams and to distribute it to various places having need of water for agriculture and other purposes. The Atharvaveda talks about drought management through efficient use of available water resources and emphasizes that these waters are used efficiently and will reduce the intensity of droughts. Verse 2.3.1 of the Atharvaveda instructs the reader for proper management of various water bodies such as brooks, wells, and pools and an efficient use of their water resources for reducing the drought intensity and water scarcity (Sharma and Shruthi, 2017). At this juncture, it would be appropriate to mention Kenoyer (2003) that stated "both Harappa and MohenjoDaro support the settlements dating to the Vedic Period". Therefore, more research work is needed for the Vedic Period (1500-500 BCE) coupled with archeological investigations.

Agriculture and livestock rearing occupied a prominent role during the Jainism and Buddhism period (600 BCE), and channel irrigation was in vogue (Bagchi and Bagchi, 1991). Field embankments were constructed surrounding the fields to increase water holding capacity at strategic points with sluice gates to harness river water with proper regulation facilities (Arthashastra), and irrigation through conduits was in practice to deliver water to the irrigation field for attaining higher efficiency (Bagchi and Bagchi, 1991). Literature suggests that a large number of hydraulic structures (dams, canals and lakes) were built during the Mauryan period in the Indo-Gangetic Plain and other parts of the country for irrigation and drinking purposes (Shaw et al., 2007; Sutcliffe et al., 2011). Many of these structures were equipped with spillways as a safety measure against incoming large floods. 


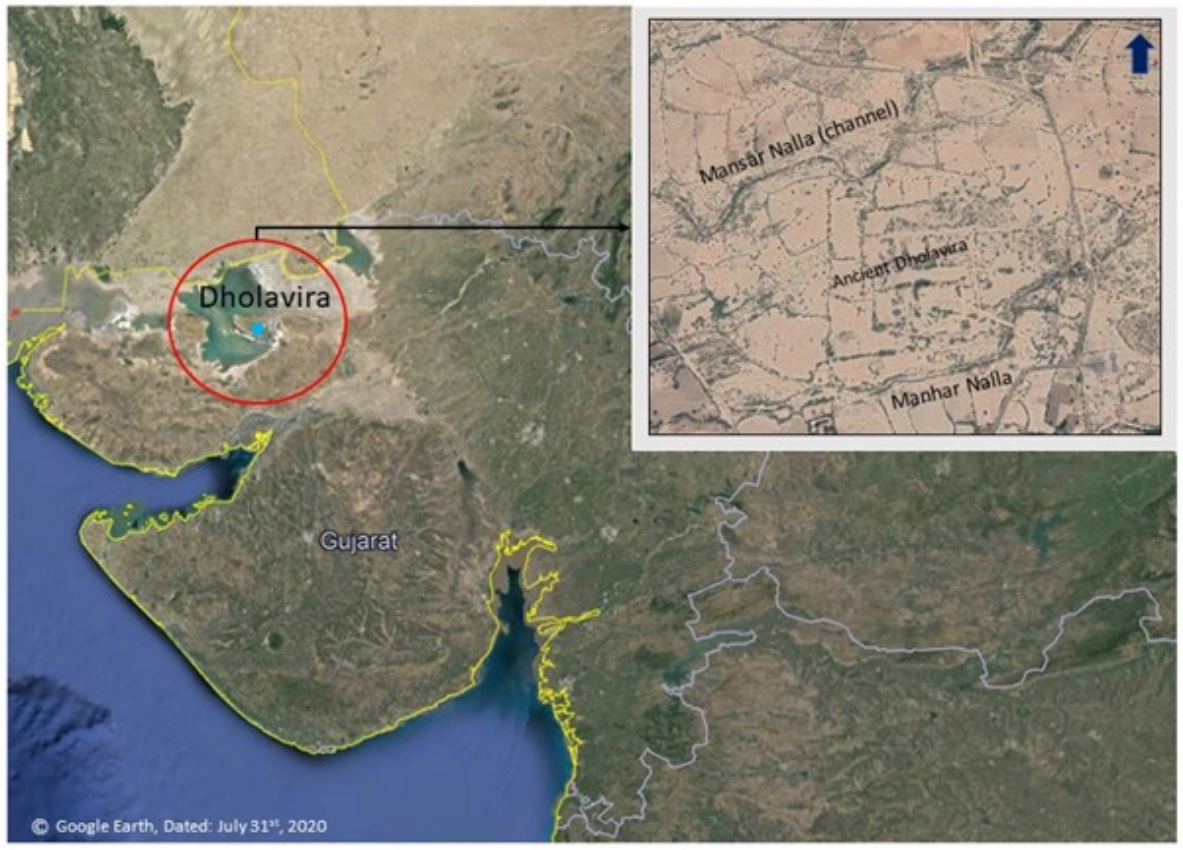

Figure 4. Location of ancient Dholavira city (ㄷ Google Earth).

During the Mauryan Empire (400-184 BCE), the emperor Chandragupta Maurya constructed Sudarsana dam in Girnar, Junagadh, Gujarat. Subsequent structural improvements involved the addition of conduits during the reign of Asoka the Great, by his provincial governor the "Yavana Administrator (Greek Administrator)", Tusaspha (Kielhorn, 1906; Shaw and Sutcliffe, 2001). In an excavation work conducted by the Archaeological Survey of India (ASI) during 19511955, in Kumhrar (the site of ancient Pataliputra), which is a few miles south of Patna, Bihar, "a canal 45 feet broad 10 feet deep and traced up to the length of 450 feet" was found, which is possibly belonging to the Mauryan period. The canal was linked with the "Sone river" and also with the "Ganges" for navigation purposes and also for providing irrigation to the adjoining area (Bhattacharya, 2012).

Similarly, as discussed in Sect. 1, the Ahar-Pyne system of the Mauryan Empire is an excellent example of a hydraulic structure used for rainwater harvesting and participatory irrigation management, and it is still widely practiced in the regions of the southern Bihar and Chhota Nagpur (Naz and Subramanian, 2010; Pant and Verma, 2010). The Pynes are constructed channels to utilize the river water flowing through the hilly regions, whereas the Ahars are catchments with embankments on three sides to store rainwater and the water from the Pynes. The Pynes feed many Ahars and several distributaries are then constructed from both Pynes and Ahars for irrigating the field (Sengupta, 1985; Verma, 1993). The Ahar-Pyne system is extremely well suited for regions that have a scanty rainfall, highly undulating and rocky terrain, soils with heavy clay or loose sand (lower moisture holding capacity), and steep slopes, thus causing extensive surface runoff. The Ahar-Pyne system also works as flood mitigation system (Roy Choudhry, 1957). The Pynes are of different sizes. If the Pynes are originating from the Ahars, then these are smaller in size ( 3 to $5 \mathrm{~km}$ ) and used for irrigating cultivable fields, whereas if these Pynes are originating from the rivers, then the size may vary from 16 to $32 \mathrm{~km}$ in length and some of them are known as "dasianpynes" (Pynes with 10 branches) to irrigate many thousand acres of the land (O'Malley, 1919). Apart from being a participatory irrigation system, the Ahar-Pyne system also works as a flood mitigation system (Roy Choudhry, 1957). It is worth mentioning here that recently the Government of Bihar has taken up renovation of the traditional water bodies (Ahar-Pyne system) under the "Jal Jeevan Hariyali" program (Water Resources Department, 2020) as shown in Fig. 5. This reflects the importance of this ancient hydraulic structure for water harvesting even in the modern times in India.

In this context, it is instructive to quote Bhattacharya (2012):

by the beginning of $300 \mathrm{BCE}$, a firm administrative setup had taken shape. As a recognition of high position accorded to agriculture by the rulers as well as the people at large, the construction of tanks and other types of reservoirs was considered to be an act of religious merit. Here the religious merit indicates "the welfare and wellbeing of the society". The Arthashastra mentions that "He (the King) shall construct reservoirs (sétu) filled with water either perennial or drawn from some other 


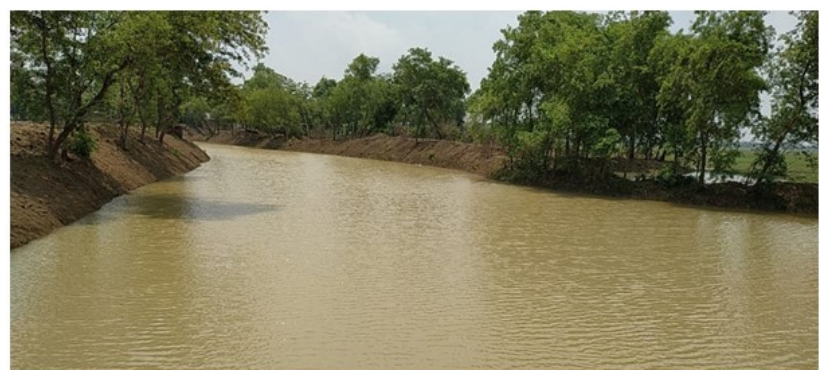

Figure 5. Renovated Ahar-Pyne system in Bihar, India (photo courtesy of Jal Jeevan Hariyali mission, Bihar, India).

source. Or he may provide with sites, roads, timber, and other necessary things to those who construct reservoirs of their own accord". Similarly, construction of places of pilgrimage (punyasthána) and of groves was given a great importance. The king, with the help and advice of his tiers of officials, ministers, and consultants started acting as the "Chief trustee" for optimizing, rationalizing, and overall management of water resources. The Arthashastra of Kautilya gives us an idea of principles and methods of management of irrigation systems... that the Mauryan kings took keen interest in the irrigation schemes is borne by the report of Megasthenes (a Greek traveler), who mentions a group of officers responsible for superintending the rivers, measuring the land as is done in Egypt, and inspecting the sluices through which the water is released from the main canals into their branches so that everyone may have an equal supply.

Shaw and Sutcliffe (2001) presented hydrological background of the historical development of water resources in South Asia with particular emphasis on ancient Indian irrigation system at the Sanchi site (a well-known Buddhist site and a UNESCO World Heritage site located in Madhya Pradesh). They investigated a 16-reservoir complex located in the Betwa river subbasin (a tributary of Yamuna in Ganga basin) in Madhya Pradesh, India, during 1998 and 2005 (Shaw, 2000; Shaw et al., 2007; Shaw and Sutcliffe, 2001, 2003a, b, 2005). In addition to Sanchi, four other known Buddhist sites of Morel-khurd, Sonari, Satdhara, and Andher, all established between 300 and 200 BCE (Cunningham, 1854; Marshall, 1940), were also surveyed by them. The rainfall is highly seasonal in this area, and about $90 \%$ of the rainfall occurs in the period between mid-June and September. There is a period of water deficit from January to June (when evapotranspiration exceeds rainfall) followed by a period from July to September (rainfall exceeds evapotranspiration) (Shaw and Sutcliffe, 2001).

The heights of the dams were found to vary from 1 to $6 \mathrm{~m}$ and their lengths from 80 to $1400 \mathrm{~m}$ with flat downstream faces; presumably designed to reduce damage from overtopping. At least two of the larger dams were equipped with spillways, which could pass floods of about a 50-year return period, and it suggests that flood protection was also taken into account while designing these structures (Shaw and Sutcliffe, 2003a). Their reservoir volumes range from 0.03 to $44.7 \times 10^{6} \mathrm{~m}^{3}$ and these estimates are closely related to the runoff generated by their catchments based on the present hydrological conditions. These dams were constructed to a height sufficient to ensure that the reservoir volume would be closely related to the volume of runoff from the upstream catchment of each site (Shaw and Sutcliffe, 2001). This indicates that these structures would have been constructed based on the detailed hydrological investigations of the region. These dams were specifically built for irrigation purposes, particularly for irrigation of rice (Shaw and Sutcliffe, 2001). According to Shaw and Sutcliffe (2005), it is more likely that the Sanchi reservoirs were part of the complementary irrigation systems providing extensive irrigation for rice cultivation and would have also supplemented rabi crops due to higher moisture holding capacity of the black cotton soils found in that region. More or less identical spillways were also found with a group of much smaller reservoirs in the neighboring Devni Mori area of Gujarat (Mehta, 1963). There are close similarities between the Sanchi dams and a well-known Sudarsana dam (Shaw and Sutcliffe, 2003b). Sutcliffe et al. (2011) opines that it is likely that some of the larger dams in the Sanchi area may have been fitted with similar spillways, which have subsequently been obscured by siltation or erosion.

According to Shaw and Sutcliffe (2001), a close relationship between runoff and reservoir volume in the Sanchi area suggests a high level of understanding of water balance based on considerable period of observation and understandings of local conditions. While excavating the area around the "Heliodorus" pillar in Vedisa (present-day Vidisha, Madhya Pradesh), Bhandarkar (1914) found the remains of a 300 BCE canal, which would have been drawing water from the river Betwa. However, Shaw and Sutcliffe (2001) further mention that a more comprehensive understanding of ancient Indian irrigation would have been developed had adequate attention been paid to the Sanchi reservoir complex during the Vedisa excavations. Based on these findings, Shaw and Sutcliffe (2003a, b) and Sutcliffe et al. (2011) conclude that the Sanchi dam system would have been built on the basis of a sound knowledge of the principles of water balance with detailed hydrological investigations and by "engineers with experience of reservoir irrigation" with a higher level of understanding of hydraulic technology.

During the Sangam Period (300 BCE to 300 AD), in the southern parts of India, the rainwater-harvesting structures such as tanks (ery in Tamil) were constructed for irrigating the paddy fields (Fardin et al., 2013; Sita, 2000), and fishing was also practiced in lotus ponds (tamaraikulam in Tamil) (Sita, 2000). The Grand Anicut (Kallanai Dam) was con- 
structed by the Chola King Karikalan during the first century $\mathrm{AD}$ on the river Cauvery for protection of the downstream populations against flood and to provide for irrigation supplies in the Cauvery delta region. The Grand Anicut is the world's oldest still in use dam and is also credited with being the fourth oldest dam in the world and the first in India. In Brihat Samhita (550 AD), there are references regarding the orientation of ponds, bank protection through pitching, plantation, and also sluicing arrangements. Brihat Samhita contains many references regarding the orientation of ponds so as to store and conserve water efficiently (reducing evaporation losses), plantation type for bank protection, and proper sluicing to protect the pond or reservoir from any possible damage. Verse 54.118 mentions that a pond oriented in an east-to-west direction retains water for a long time, while one oriented from north to south loses invariably by the waves raised by the winds. Verse 54.120 suggests that construction of a spillway as an outlet for the water should be made on a side with the passage being laid with stones.

\section{Wastewater management in ancient India}

Sanitation and wastewater management has always been one of the most important socio-environmental challenges that humankind has ever faced and the societies in ancient India had developed state-of-the-art technological solutions by utilizing their knowledge of hydraulic systems with structural and material advancements.

The Harappan cities were one of the very first and most urbanized centers developed with excellent civil and architectural knowledge in the Old World. Even as early as 2500 BCE, Harappa and Mohenjo-Daro included the world's first urban sanitation systems (Webster, 1962). Lofrano and Brown (2010) presented an in-depth review of wastewater management in the history of mankind and found that the "Indus Valley civilization was the first to have proper wastewater treatment systems" in those ancient times. Wastewater management and sanitation were the major characteristics of the first urban sites of the Harappan civilization (Kenoyer, 1991). The sewage and drainage systems were composed of complex networks, especially in Mohenjo-Daro and Harappa (Jansen, 1989). Latrines, soak pits, cesspools, pipes, and channels were the main elements of wastewater disposal (Fardin et al., 2013).

All the houses were connected to the drainage channels, which were covered with bricks and cut stones, and the household wastewater was first collected through tapered terracotta pipes into the small sumps for sedimentation and removal of larger contaminants (primary wastewater treatment) and then into drainage channels in the street. This most likely was the first attempt at wastewater treatment on record (Lofrano and Brown, 2010). The pipes were built with well-burned bricks (Gray, 1940) having U-shaped cross sections and set in clay mortar with various coverings (brick slabs, flagstones, or wooden boards); they could be removed easily for cleaning the pipes. These ancient terracotta pipes are the precursor of our modern vitrified clay spigot-andsocket sewer pipes (Gray, 1940). These drainage channels had the provision of cleaning and maintenance by removing the bricks and cut stones (Wolfe, 1999). The cesspits were fitted at the junction of several drains to avoid clogging of the drainage systems (Wright, 2010).

Multiple flushing lavatories attached to a sophisticated sewage system were provided in the ancient cities of Harappa and Mohenjo-Daro (Pruthi, 2004). The Great Bath at Mohenjo-Daro and the 16 reservoir system of the Dholavira as well as the dockyard are perfect examples of the excellent hydraulic engineering in the Harappan civilization.

Fardin et al. (2013) mention that almost all the settlements of Mohenjo-Daro were connected to the drain network. However, at the same time, at Kalibangan, toilets and bathroom outflows were connected in U-shaped channels made of wood or terracotta bricks with decentralized sewage systems. These effluents poured into a jar placed in the main street (Chakrabarti, 1995). The same model of wastewater collection was used in Banawali, where effluents were channeled into drains made of clay bricks before reaching the jars (Bisht, 1984). Several types of stone and terracotta conduits and pipes were also used to transfer water, drain storm water, and wastewater in the Minoan civilization (ca. 32001100 BCE) (De Feo et al., 2014).

In many other parts of ancient India, e.g., Jorwe (Maharashtra), a similar drainage system was established during 1375-1050 BCE (Fardin et al., 2013; Kirk, 1975). Apart from the detailed references to various aspects of hydrology as discussed earlier, we also get some references to water quality in Vedas and other early literature, especially in Atharvaveda, Charaka Samhita, and Susruta Samhita (both of the pre- and early Buddhist era) (NIH, 2018). There are hymns in Rigveda stating the role of forest conservation and tree plantation on water quality (verse V, 83.4). Verse V, 22.5, of Atharvaveda cautioned people from diseases living in a region with heavy rainfall and bad quality of water. There are instances of classifying water based on taste in epic Mahabharata (verse XII, 184.31 and 224.42). The Brihat Samhita also discussed the relationship between soil color and water quality (verse 54.104), and techniques are mentioned for obtaining potable water with medicinal properties from contaminated water (verses 54.121 and 54.122).

At around $500 \mathrm{BCE}$, the city of Ujjain was also provided with a sophisticated drainage system having soak pits built of pottery-ring or pierced pots (Kirk, 1975; Mate, 1969). In Taxila around $300 \mathrm{BCE}$, a very much similar drainage system to that of Mohenjo-Daro was in place (Singh, 2009). This shows that during ancient times, modern concepts of sanitation and wastewater management technology were very well known to the Indians and were in their advanced stages during the Indus Valley civilization and later periods. 


\section{Hydraulic interlinkages between the ancient Indian and nearby cultures}

All the ancient civilizations, i.e., Harappan, Egyptian, Mesopotamian, Chinese, and Minoan, that flourished and attained their pinnacle were largely dependent on the degree or extent of their advancements in water technologies. With efficient management of water resources, they were able to produce more food grains and mitigate the damages due to natural hazards such as droughts and floods. At the same time, the advanced wastewater management techniques helped in healthy lifestyles, hygiene, and clean environments. The ancient Indian literature covering the period from the Harappan civilization to the Vedic Period followed by the Mauryan Empire, including the hymns and prose in Vedic Samhitas and Puranas, contains detailed discourses on the various processes of the hydrological cycle, including groundwater exploration, water quality, well construction, and irrigation by channels (kulya). Water technological advancements coupled with the architectural sophistication during the Harappan civilization were at their zenith. Nowhere in the contemporary world can such a sophisticated and impressive planning relating to the water supply and effluent disposal system be found (Jansen, 1989). Almost all houses had private wells with bath and toilet area lined with the standard size burned bricks and draining into the soak pit or into the street drains.

The effluent disposal drainage systems were well known to almost all the civilizations at that time with varying levels of technological advancements. The Egyptian civilization ( 2000-500 BCE) lacked flushing lavatories and sophisticated sewer and wastewater disposal systems at that time as was prevalent in the Harappan civilization. Copper pipes were in use in some pyramids for building bathrooms and sewerage systems (De Feo et al., 2014). The Mesopotamian civilization (ca. 4000-2500 BCE) also had well-constructed storm drainage and sanitary sewer systems. However, there seems to be no system of vertical water supply by means of wells, and it was even practically unknown in the early urban cultures (Jansen, 1989; De Feo et al., 2014). According to Jansen (1989) and De Feo et al. (2014), very efficient drainage and sewerage systems and flushing toilets, which can be compared to the modern ones, were re-established in Europe and North America a century and a half ago.

Mohenjo-Daro was serviced by at least 700 wells, whereas the contemporary Egyptians and Mesopotamians had to fetch water, bucket by bucket, from the river and then store the water in tanks at home (Jansen, 1989). The bathing platforms in the Harappan civilization were also unique compared to the Mesopotamian and other civilizations. The ancient cities of the Mesopotamian civilization, i.e., Ur and Babylon, had effective drainage systems for storm water control, sewers and drains for household waste, and drains specifically for surface runoff (Jones, 1967; Maner, 1966). The ancient Mesopotamians had also developed canal irrigated agriculture and constructed dams across the Tigris river for divert- ing water to meet the irrigation and domestic supplies. The "qanat" systems were widely used in the Mesopotamian civilization for transferring water from one place to another using gravity. The urban centers of the Sumer (Sumerian) and Akkad (Akkadian) (third millennium BCE) had water supplies by canal(s) connected to the Euphrates river. The waterlifting devices were also used in the Mesopotamian civilization, and the Saqia (or water wheel) was widely used for lift irrigation using oxen for irrigating the summer crops (Mays, 2008). The "asma-cakra" and "Ghatayantra" were widely in use during the Vedic and Mauryan periods. The Varshamaan was widely used in the Mauryan Empire for rainfall measurements. It may be noted that we do not have any reference to "rainfall measurement" in other contemporary civilizations in the Old World. The Ahar-Pyne system of participatory irrigation and rainwater harvesting is a unique system developed in ancient India. The water fortification (audaka) around the forts was also a prime requirement in the Mauryan Empire.

In the Chinese (Hwang-Ho) civilization, the Shang Dynasty (1520-1030 BCE) developed extensive irrigation works for rice cultivation. Various water works such as dikes, dams, canals, and artificial lakes proliferated across the Chinese civilization. During the period 1100-221 BCE, Lingzhi city (covering an area of $15 \mathrm{~km}^{2}$ ) also had a complex water supply and drainage system, which was combined with the river, drainage raceway, pipeline, and moat (De Feo et al., 2014). The underground urban drainage systems were also in existence in China during the Shang Dynasty $(\sim 10$ $15 \mathrm{BCE})$.

The Minoan civilization ( 3200-1100 BCE) is considered to be the first and the most important European culture (Khan et al., 2020). Crete was the center of the Minoan civilization and was known for architectural and hydraulic operation of its water supply, sewerage, and drainage systems (Khan et al., 2020). Aqueducts made of terracotta were in use for transporting water from the mountain springs. Water cistern were used for storing rainwater and spring water for further transporting it by using aqueducts. Lavatories with a flushing system were also in use in this civilization.

In the words of Jansen (1989), "for the first time in the history of mankind, the waterworks developed in Harappan civilization were to such a perfection which was to remain unsurpassed until the coming of the Romans and the flowering of civil engineering and architecture in classical antiquity, more than 2000 years later". Overall, if we closely look at the scale of the hydro-technologies in all the civilizations, the Harappan civilization is not only credited with the more advanced and larger-scale application of hydro-technologies (hydrologic, hydraulic, and hydro-mechanical) but also worked as a "archetype" for contemporary civilizations to achieve the great heights in human civilizations, on the whole. 


\section{Decline of Harappan civilization - role of climate and natural disasters}

The decline of the Harappan civilization is still a puzzle; there is no clear reason, and the topic is still being debated in historical and scientific circles. Many factors such as climatic, economic, and political factors have been attributed to the spectacular decline of the Harappan civilization. However, no single explanation can be thought of as the sole descriptor of this decline (Lawler, 2008). Keeping in view the status and developments of the civilization, it is likely that there were multiple factors that went against the sustainability of the Harappan civilization, and nature-related factors are likely to have played a dominant role. Here we list some of the factors which might have eventually led to the decline of the Harappan civilization.

- Climate change. The dry epoch that lasted for about 900 years due to weakening of the Indian summer monsoon (around 4350 years ago) adversely impacted the agrarian society of this civilization (Das, 2018; Dixit et al., 2014). The period of a long dry spell reduced the snow cover in the northwest Himalaya, causing reduced water availability in the Indus River (Dutt et al., 2018; Kathayat et al., 2017). The reduction in water availability severely impacted agricultural systems (Sarkar et al., 2016) and production, which ultimately led to the migration of the population towards the Gangetic plains.

- Infectious diseases. The vulnerable state of Harappan society may have been compounded by concurrent social and economic changes, promoting further disintegration of the Harappan civilization. The stratified social structure and urbanization facilitated propagation of infectious diseases (leprosy, tuberculosis) within the marginalized population. These factors led to massive migration of the population from the Indus Valley around 1900 BCE (Schug et al., 2013).

- Natural disasters. The presence of silt deposits and topographic and geological anomalies suggest that the occurrence of massive floods might have caused the decline of the Harappan civilization. Tectonic disturbances might have altered the course of the Indus River, affecting the water availability for agricultural production (Dales, 1966).

\section{Summary and conclusions}

This paper has explored the hydrological developments in ancient India starting from the Harappan civilization to the Vedic Period and during the Mauryan Empire using references from Vedas; mythological epics such as Mahabharata and Ramayana; Jainist and Buddhist literature; the references to Arthashastra, Astadhyayi, and many other Vedic texts such as Puranas (Brahmana, Linga, etc.); Brihat Samhita; and other ancient literature. The following conclusions can be drawn from this investigation.

The Harappan civilization epitomizes the level of development in water sciences. Agriculture was the main economic activity of Harappan society. Extensive networks of canals, water storage structures, different types of wells, and sustainable low-cost water-harvesting structures were developed during this period. Harappans had created sophisticated water and wastewater management systems, planned networks of sewerage systems through underground drains, and also had the earliest known system of flush toilets in the world. The Harappan civilization is also credited with the firstknown dockyard in the entire world. The Harappans were also aware of the oceanic calamities such as tsunami.

The Vedas, particularly the Rigveda, Atharvaveda, and $\mathrm{Ya}$ jurveda, had specifically dwells upon the hydrologic cycle and various associated processes. The concepts of evaporation, cloud formation, water movement, infiltration and river flow, and repetition of the cycle are explicitly discussed in these ancient texts. Rigveda also mentions a water-lifting device such as Asma-cakra and Ghatyanta (similar to Noria), among others. Ramayana has also mentioned the hydrologic cycle and artesian wells. Mahabharata explains about the monsoon seasons and the water uptake process by plants. Matsya Purana, Vayu Purana, Linga Purana, and Brahmanda Purana also mention the processes of evaporation; formation of clouds due to cyclonic, convectional, and orographic effects; rainfall potential of clouds; and many other associated hydrological processes.

The Rigveda, Atharvveda, Brihat Samhita, Susruta Samhita, and Charaka Samhita have numerous references to water quality and nature-based solutions (NBS) for obtaining potable water. The Dakargalam chapter of Brihat Samhita dwelt upon the occurrence and distribution of groundwater resources using geographical pointers and soil markers.

The first observatory for measuring rainfall using Varshamaan (rain gauge) was established during the Mauryan Empire in India. The reservoirs, dams, and canals equipped with spillways were constructed for irrigation and domestic supplies with adequate knowledge of water balance. A water pricing system was developed. Some structures were also constructed that considers 50-year return periods. In water history, the Mauryan period is recognized as the first and foremost hydraulic civilization. They had also developed a system to forecast rainfall.

There are pieces of evidence to show that the Harappans had developed one of the smartest urban centers in those ancient times with an exemplary fusion of civil, architectural, and material sciences. The Indus Valley civilization is known to have developed the earliest-known system of flush toilets in the world. They had also developed sophisticated water management systems comprising a series of reservoirs, step wells, and channels.

Agriculture was practiced on a large scale having extensive networks of canals for irrigation. The irrigation sys- 
tems, different types of wells, water storage systems, and sustainable low-cost water-harvesting techniques were developed throughout the region at that time. There are many pieces of evidence that the Harappans constructed low-cost water-harvesting structures using locally available materials through public participation. Mohenjo-Daro was one of the major urban centers of the Harappan civilization receiving water from at least 700 wells and almost all houses had one private well (Angelakis and Zheng, 2015).

The Mauryan kings took keen interest in the irrigation schemes. The Ahar-Pyne system of the Mauryan Empire, an excellent example of rainwater harvesting and irrigation management, is still practiced in southern Bihar and Chhota Nagpur. A number of hydraulic structures were built during the Mauryan period for irrigation and drinking purposes. An excavation work by the Archaeological Survey of India close to Patna revealed a large canal, likely belonging to the Mauryan period, which was possibly constructed for navigation and irrigation. Interestingly, a verse of Atharvaveda mentions that those who use rainwater by means of rivers, wells, and canals for navigation, recreation, agriculture etc., prosper all the time.

Tanks (rainwater-harvesting structures) were constructed for irrigating the paddy fields in southern India about 2000 years ago. The Chola King Karikalan constructed the Grand Anicut on the Cauvery river for flood protection and for irrigation in the Cauvery delta during the first century AD.

As early as $2500 \mathrm{BCE}$, Harappa and Mohenjo-Daro had the world's first urban sanitation systems. The sewage and drainage systems were composed of complex networks connecting the houses, including latrines, soak pits, cesspools, pipes, and channels.

A number of factors might have eventually led to the collapse of the Harappan civilization: a dry epoch that lasted for about 900 years due to weakening of the Indian summer monsoon; the stratified social structure and urbanization facilitated propagation of infectious diseases; and natural disasters including the occurrence of massive floods and tectonic disturbances.

Hydrologic knowledge in ancient India was contained in the shlokas of scriptures and very few people are conversant with the languages of the scriptures. Hence, knowledge and wisdom remained largely unknown to the later generations. Further, the script of the Harappans has not yet been deciphered. If further research is carried out on ancient literature and when the script of the Harappans is deciphered, many more facts will emerge which may be much more fascinating than what we know so far.

Data availability. No data sets were used in this article.

Author contributions. PPM and SKJ conceptualized the paper and its contents. PKS, PD, SKJ, and PPM developed the structure of the paper. PKS wrote most parts of the paper; PD contributed to Sect. 5 and also contributed to referencing and formatting the article. SKJ and PPM wrote some parts of the article as well as reviewed, revised, and supervised the progress of article.

Competing interests. The authors declare that they have no conflict of interest.

Special issue statement. This article is part of the special issue "History of hydrology" (HESS/HGSS inter- journal SI). It is not associated with a conference.

Review statement. This paper was edited by Roberto Ranzi and reviewed by Stefano Barontini and one anonymous referee.

\section{References}

Agrawal, S., Majumder, M., Bisht, R. S., and Prashant, A.: Archaeological Studies at Dholavira Using GPR, Curr. Sci. India, 114, 879, 2018.

Angelakis, A. N. and Zheng, X. Y.: Evolution of Water Supply, Sanitation, Wastewater, and Stormwater Technologies Globally, Water, 7, 455-463, https://doi.org/10.3390/w7020455, 2015.

Baba, A., Tsatsanifos, C., El Gohary, F., Palerm, J., Khan, S., Mahmoudian, S. A., Ahmed, A. T., Tayfur, G., Dialynas, Y. G., and Angelakis, A. N.: Developments in water dams and water harvesting systems throughout history in different civilizations, Int. J. Hydrol., 2, 155-171, https://doi.org/10.15406/ijh.2018.02.00064, 2018.

Bagchi, K. S. and Bagchi, S. S.: History of Irrigation in India I. Irrigation in Ancient India (From 2295 Bc upto the 11th Century), Irrig. Power J., 48, 69-76, 1991.

Baker, M. N. and Horton, R. E.: Historical development of ideas regarding the origin of springs and ground-water, Eos Trans. Am. Geophys. Union, 17, 395-400, 1936.

Bhandarkar, D. R.: Excavations at Besnagar, Annual Reports, Archaeological Survey of India, Calcutta, 1914.

Bhattacharya, P. K.: Sectional President's Address: Irrigation and Agriculture In Ancient India, Proc. Indian Hist. Congr., 73, 1834, available at: https://www.jstor.org/stable/44156186 (last access: 27 April 2020), 2012.

Bindra, S. C.: Lothal: A Harappan port town revisited, Purātattva, 33, 1, 2003.

Bisht, R. S., Lal, B. B., and Gupta, S. P. (Eds.): Structural remains and town planning of Banawali, in: Frontiers of the Indus Civilization: Sir Mortimer Wheeler Commemoration Volume, pp. 89-98, Books \& Books, New Delhi, 1984.

Biswas, A. K.: History of hydrology, North-Holland Publishing Company, Amsterdam, 1969.

Chakrabarti, D. K.: The archaeology of ancient Indian cities, Oxford University Press, USA, 1995.

Chase, B., Ajithprasad, P., Rajesh, S. V., Patel, A., and Sharma, B.: Materializing Harappan identities: Unity and diversity in the borderlands of the Indus Civilization, J. Anthropol. Archaeol., 35, 63-78, https://doi.org/10.1016/j.jaa.2014.04.005, 2014. 
Chow, V. T.: Handbook of Applied Hydrology: A Compendium of Water-resources Technology, 1st Edn, McGraw-Hill Company, New York, NY, 1964.

Chow, V. T.: Contributions of Asian civilizations to the concept of the hydrological cycle, UNESCO, available at: http:// agris.fao.org/agris-search/search.do?recordID=FD7502194 (last access: 27 April 2020), 1974.

Cunningham, S. A.: The Bhilsa Topes: Or, Buddhist Monuments of Central India, Smith, Elder \& Company, London, 1854.

Dales, G. F.: The decline of the Harappans, Sci. Am., 214, 92-101, available at: https://www.jstor.org/stable/24930939 (last access: 11 July 2020), 1966.

Das, B.: A prolonged drought destroyed Indus Valley Civilisation, new study says, Nature India, available at: https: //www.natureasia.com/en/nindia/article/10.1038/nindia.2018.61 (last access: 11 July 2020), 2018.

De Feo, G. and Napoli, R. M. A.: Historical development of the Augustan Aqueduct in Southern Italy: twenty centuries of works from Serino to Naples, Water Supply, 7, 131-138, https://doi.org/10.2166/ws.2007.015, 2007

De Feo, G., Antoniou, G., Fardin, H. F., El-Gohary, F., Zheng, X. Y., Reklaityte, I., Butler, D., Yannopoulos, S., and Angelakis, A. N.: The Historical Development of Sewers Worldwide, Sustainability-Basel, 6, 3936-3974, https://doi.org/10.3390/su6063936, 2014.

Dixit, Y., Hodell, D. A., and Petrie, C. A.: Abrupt weakening of the summer monsoon in northwest India $\sim 4100 \mathrm{yr}$ ago, Geology, 42, 339-342, https://doi.org/10.1130/G35236.1, 2014.

Dixit, Y., Hodell, D. A., Giesche, A., Tandon, S. K., Gázquez, F., Saini, H. S., Skinner, L. C., Mujtaba, S. A. I., Pawar, V., Singh, R. N., and Petrie, C. A.: Intensified summer monsoon and the urbanization of Indus Civilization in northwest India, Sci. Rep., 8, 1-8, https://doi.org/10.1038/s41598-018-22504-5, 2018.

Dooge, J. C. I.: Background to modern hydrology, in: The Basis of Civilisation - Water Science?, edited by: J. C. Rodda and L. Ubertini, pp. 3-12, IAHS Press, Wallingford, UK, 2004.

Dutt, S., Gupta, A. K., Wünnemann, B., and Yan, D.: A long arid interlude in the Indian summer monsoon during $\sim 4,350$ to 3,450 cal. yr BP contemporaneous to displacement of the Indus valley civilization, Quatern. Int., 482, 83-92, https://doi.org/10.1016/j.quaint.2018.04.005, 2018.

Fardin, H. F., Hollé, A., Gautier, E., and Haury, J.: Wastewater management techniques from ancient civilizations to modern ages: examples from South Asia, Water Supply, 13, 719-726, https://doi.org/10.2166/ws.2013.066, 2013.

Goswami, C.: Śrimad Valmiki-Rāmāyaa: with Sanskrit text and English translation, Gita Press, Gorakhpur, 1973.

Glucklich, A.: The Strides of Vishnu: Hindu Culture in Historical Perspective, Oxford University Press, Oxford, New York, 2008.

Gray, H. F.: Sewerage in Ancient and Mediaeval Times, Sewage Works J., 12, 939-946, available at: https://www.jstor.org/stable/ 25029094 (last access: 8 July 2020), 1940.

Horton, R. E.: The field, scope, and status of the science of hydrology, Eos Trans. Am. Geophys. Union, 12, 189-202, https://doi.org/10.1029/TR012i001p00189-2, 1931.

Iyer, M.: The best laid plans, Deccan Herald, available at: https://www.deccanherald.com/sunday-herald/ best-laid-plans-713650.html (last access: 27 April 2020), 2019.
Iyer, N. C.: Brihat Samhita of Varaha Mihira, Cent. Secr. Libr., South Indian Press, Madura, pp. 1-258, available at: http: //cslrepository.nvli.in//handle/123456789/4675 (last access: 28 April 2020), 1884.

Jain, S. K., Agarwal, P. K., and Singh, V. P.: Hydrology and Water Resources of India, Springer Science \& Business Media, Dordrecht, 2007.

Jansen, M.: Water supply and sewage disposal at Mohenjo-Daro, World Archaeol., 21, 177-192, https://doi.org/10.1080/00438243.1989.9980100, 1989.

Jones, D. E.: Urban hydrology - a redirection, Civil. Eng., 37, 58, 1967.

Jha, P. A. (Ed.): Vrhat Sanhita (550 AD) by Varahmihira, Chow Khamba Vidyabhawan, Varanasi, 1988.

Jigyasu, B.: Ashtadhyayi (bhashya) prathamavrtti, three volumes, Ramlal Kapoor Trust, Bahalgadh, 1979.

Kathayat, G., Cheng, H., Sinha, A., Yi, L., Li, X., Zhang, H., Li, H., Ning, Y., and Edwards, R. L.: The Indian monsoon variability and civilization changes in the Indian subcontinent, Science Advances, 3, e1701296, https://doi.org/10.1126/sciadv.1701296, 2017.

Kenoyer, J. M.: The Harappan state: was it or wasn't it: Prehistory Press, Madison, WI, USA, 1994.

Kenoyer, J. M.: The Indus Valley Tradition of Pakistan and western India, J. World Prehist., 5, 331-385, https://doi.org/10.1007/BF00978474, 1991.

Kenoyer, J. M.: Ancient cities of the Indus valley civilization, American Institute of Pakistan Studies, Oxford University Press, Karachi, 1998.

Kenoyer, J. M.: Uncovering the keys to the lost Indus cities, Sci. Am., 289, 66-75, available at: https://www.jstor.org/stable/ 26060364 (last access: 27 April 2020), 2003.

Khan, S.: Sanitation and wastewater technologies in Harappa/Indus valley Civilization (ca. 2600-1900 BC), in: Evolution of Sanitation and Wastewater Technologies through the Centuries, 25, IWA Publishing, London, 2014.

Khan, S., Dialynas, E., Kasaraneni, V. K., and Angelakis, A. N.: Similarities of Minoan and Indus Valley Hydro-Technologies, Sustainability-Basel, 12, 4897 , https://doi.org/10.3390/su12124897, 2020.

Kielhorn, F.: Junagadh rock inscription of Rudradaman: the year 72, Epigraphia Indica, VIII, pp. 36-49, 1906.

Kirk, W.: The Role of India in the Diffusion of Early Cultures, Geogr. J., 141, 19-34, https://doi.org/10.2307/1796941, 1975.

Lawler, A.: Indus collapse: The end or beginning of an Asian culture?, Science, 320, 1281-1283, 2008.

Lofrano, G. and Brown, J.: Wastewater management through the ages: A history of mankind, Sci. Total Environ., 408, 5254-5264, 2010.

Malik, S.: Conceptual Aspect of Hydrological Cycle in Indian Mythology of Kishkindha Kanda, Ramayana, J. Environ. Earth Sci., 6, 54-59, available at: https://www.iiste.org/Journals/index. php/JEES/article/view/30032 (last access: 27 April 2020), 2016.

Maner, A. W.: Public works in ancient Mesopotamia, Civil. Eng., 36, 50-51, 1966.

Marshall, S. J. H.: The Monuments of Sanchi, Swati Publications, Delhi, 1940.

Mate, M. S.: Building in ancient India, World Archaeol., 1, 236246, https://doi.org/10.1080/00438243.1969.9979442, 1969. 
Mays, L. W.: A very brief history of hydraulic technology during antiquity, Environ. Fluid Mech., 8, 471-484, 2008.

McClellan III, J. E. and Dorn, H.: Science and Technology in World History: An Introduction, JHU Press, Baltimore, 2015.

Mckean, M. B.: The Palynology of Balakot, a Pre-Harappan and Harappan Age Site in Las Bela, Pakistan, PhD thesis, Southern Methodist University, Dallas, Texas, USA, available at: https: //elibrary.ru/item.asp?id=7412156 (last access: 27 April 2020), 1985.

Mehta, R. N.: Ancient bunds in Sabarkantha district, Gujarat, J. Orient. Inst. MS Univ. Baroda, 10, 359-365, 1963.

Miller, H. M.-L.: Water supply, labor requirements, and land ownership in Indus floodplain agricultural systems, in: Agricultural Strategies, pp. 92-128, Cotsen Institute of Archaeology, UCLA, Los Angeles, 2006.

Miller, H. M. L., Morehart, C. T., and De Lucia, K. (Eds.): Surplus in the Indus Civilisation, agricultural choices, social relations, political effects, in: Surplus: The Politics of Production and the Strategies of Everyday Life, University Press of Colorado, Boulder, 2015.

Mukerji, R. K.: Ancient Indian education: Brahmanical and Buddhist, Motilal Banarsidass, Delhi, 1960.

Mujumdar, P. P. and Jain, S. K.: Hydrology in Ancient India: Some Fascinating Facets, in: EGU General Assembly Conference Abstracts, Vienna, Austria, 8-13 April 2018, 20, p. 8690, 2018.

Murty, K. S.: Varahamihira, the Earliest Hydrologist, in: Water for the Future: Hydrology in Perspective, IAHS Publication, Wallingford, Oxfordshire, UK, 164, 1987.

Nair, K. S.: Role of water in the development of Civilizationin India - a review of ancient literature, traditional practices and beliefs, Int. Assoc. Hydrol. Sci., 286, 160-166, 2004.

Naz, F. and Subramanian, S. V.: Water management across space and time in India, Working Paper, ZEF Working Paper Series, available at: https://www.econstor.eu/handle/10419/88305 (last access: 7 July 2020), 2010.

Nigam, R., Dubey, R., Saraswat, R., Sundaresh, Gaur, A. S., and Loveson, V. J.: Ancient Indians (Harappan settlement) were aware of tsunami/storm protection measures: a new interpretation of thick walls at Dholavira, Gujarat, India, Curr. Sci. India, 111, 2040-2043, available at: https://www.jstor.org/stable/ 24911592 (last access: 27 April 2020), 2016.

NIH, Jain, S. K., Lohani, A. K., Khobragade, S. D., Singh, P. K., Ullah, F., and Pandey, C. (Eds.): Hydrologic Knowledge in Ancient India, National Institute of Hydrology, Jal Vigyan Bhavan, Roorkee, India, 2018.

Olson, R. G.: Technology and Science in Ancient Civilizations, ABC-CLIO, Santa Barbara, California, 2009.

O'Malley, L. S. S.: Bengal District Gazetters-Gaya, Superintendent, Government Printing, Bihar and Orissa, Calcutta, 146-147, 1919.

Ortloff, C. R.: Water engineering in the ancient world Archaeological and climate perspectives on societies of ancient South America, the Middle East, and South-East Asia, Oxford University Press, New York, USA, 2009.

Pant, N. and Verma, R. K.: Tanks in Eastern India: A Study in Exploration, International Water Management Institute, Hyderabad, 2010.

Petrie, C. A. and Bates, J.: 'Multi-cropping', Intercropping and Adaptation to Variable Environments in Indus South Asia, J.
World Prehist., 30, 81-130, https://doi.org/10.1007/s10963-0179101-z, 2017.

Petrie, C. A., Singh, R. N., Bates, J., Dixit, Y., French, C. A. I., Hodell, D. A., Jones, P. J., Lancelotti, C., Lynam, F., Neogi, S., Pandey, A. K., Parikh, D., Pawar, V., Redhouse, D. I., and Singh, D. P.: Adaptation to Variable Environments, Resilience to Climate Change: Investigating Land, Water and Settlement in Indus Northwest India, Curr. Anthropol., 58, 1-30, https://doi.org/10.1086/690112, 2017.

Petrie, C. A. and Yoffee, N. (Ed.): The Evolution of Fragility: Setting the Terms, McDonald Institute for Archaeological Research, Cambridge, UK, 2019.

Possehl, G. L.: Sociocultural complexity without the State. The Indus Civilization, in: Archaic states, vol. School of American Research advanced seminar series, edited by: Feinman, G. M. and Marcus, J., pp. 261-291, School of American Research Press, Santa Fe, NM, 1998.

Possehl, G. L.: The Indus Civilization: an introduction to environment, subsistence, and cultural history, in: Indus ethnobiology, edited by: S. Weber and W. Belcher, pp. 1-20, 2003.

Possehl, G. L.: The Indus civilization: a contemporary perspective, Rowman Altamira, Lanham, Maryland, USA, 2002.

Prasad, E. A. V.: Ground water in Varahamihira's Vrhat Sanhita: Masslit. series No. 1, Sri Venkateswara University Press, Tirupathi, India, 1980.

Prasad, E. a. V.: Bioindicators of Ground Water in Varahamihira's Brihat Samhita, Groundwater, 24, 824-828, https://doi.org/10.1111/j.1745-6584.1986.tb01703.x, 1986.

Pruthi, R.: Prehistory and Harappan civilization, APH Publishing, New Delhi, 2004.

Rao, S. R.: Lothal - A Harappan Port Town, vol. 1, Mem. Archaeol. Surv. India, 78, 83-84, 1979.

Roy Choudhry, P. C.: Bihar District Gazetters, Gaya, Government of Bihar, Patna, 205, 1957.

Sarasvati, S. P.: Rig Veda, DAV Publication Division, New Delhi, 2009.

Sarkar, A., Mukherjee, A. D., Bera, M. K., Das, B., Juyal, N., Morthekai, P., Deshpande, R. D., Shinde, V. S., and Rao, L. S.: Oxygen isotope in archaeological bioapatites from India: Implications to climate change and decline of Bronze Age Harappan civilization, Sci. Rep., 6, 26555, https://doi.org/10.1038/srep26555, 2016.

Scarborough, V. L.: The Flow of Power: Ancient Water Systems and Landscapes, 1 edition, School of American Research Press, US, Santa Fe, NM, 2003.

Schug, G. R., Blevins, K. E., Cox, B., Gray, K., and MushrifTripathy, V.: Infection, Disease, and Biosocial Processes at the End of the Indus Civilization, PLOS One, 8, e84814, https://doi.org/10.1371/journal.pone.0084814, 2013.

Sen, S. N.: Ancient Indian history and civilization, New Age International, New Delhi, 1999.

Sengupta, N.: Irrigation: Traditional vs Modern, Econ. Polit. Weekly, 20, 1919-1938, available at: https://www.jstor.org/ stable/4375013 (last access: 7 July 2020), 1985.

Shamasastry, R.: Kauilya's Arthaśāstra, Mysore Printing and Publishing House, Mysuru, Karnataka, India, 1961.

Sharma, S. and Shruthi, M. S.: Water in Hindu Scriptures: Thank You, Water!, in: Water and Scriptures: Ancient Roots for Sustainable Development, edited by: K. V. Raju and S. Manasi, pp. 
89-172, Springer International Publishing, Cham, Switzerland, 2017.

Shaw, J.: Sanchi and its archaeological landscape: Buddhist monasteries, settlements \& irrigation works in Central India, Antiquity, 74, 775-776, https://doi.org/10.1017/S0003598X00060397, 2000.

Shaw, J. and Sutcliffe, J.: Ancient irrigation works in the Sanchi area: an archaeological and hydrological investigation, South Asian Stud., 17, 55-75, https://doi.org/10.1080/02666030.2001.9628592, 2001.

Shaw, J. and Sutcliffe, J.: Ancient dams, settlement archaeology and Buddhist propagation in central India: the hydrological background, Hydrol. Sci. J., 48, 277-291, https://doi.org/10.1623/hysj.48.2.277.44695, 2003a.

Shaw, J. and Sutcliffe, J.: Water Management, Patronage Networks and Religious Change: New evidence from the Sanchi dam complex and counterparts in $\mathrm{Gu}-$ jarat and Sri Lanka, South Asian Stud., 19, 73-104, https://doi.org/10.1080/02666030.2003.9628622, 2003b.

Shaw, J. and Sutcliffe, J.: Ancient Dams and Buddhist Landscapes in the Sanchi area: New evidence on Irrigation, Land use and Monasticism in Central India, South Asian Stud., 21, 1-24, https://doi.org/10.1080/02666030.2005.9628641, 2005.

Shaw, J., Sutcliffe, J., Lloyd-Smith, L., Schwenninger, J.-L., and Chauhan, M. S.: Ancient Irrigation and Buddhist History in Central India: Optically Stimulated Luminescence Dates and Pollen Sequences from the Sanchi Dams, Asian Perspect., 46, 166-201, available at: https://www.jstor.org/stable/42928709 (last access: 27 April 2020), 2007.

Singh, U.: A History of Ancient and Early Medieval India: From the Stone Age to the 12th Century (PB), Pearson Education India, New Delhi, 2009.

Sita, K.: Irrigation system of the Sangam Tamils, in: Irrigation system of the Sangam Tamils, pp. 29-36, Rajesh Publications, Nagercoil, 2000.

Sorcinelli, P.: Storia sociale dell'acqua: riti e culture, Pearson Italia SpA, Milan, Italy, 1998.

Srinivasan, T. M.: Water Lifting Devices in Ancient India: Their Origin and Mechanisms, Indian J. Hist. Sci., 5, 379-389, available at: https://insa.nic.in/writereaddata/UpLoadedFiles/IJHS/ Vol05_2_15_TMSrinivasan.pdf, 1970.

Srinivasan, T. M.: Measurement of Rainfall in Ancient India, Indian J. Hist. Sci., Calcutta, 11, 148-157, 1976.

Sutcliffe, J., Shaw, J., and Brown, E.: Historical water resources in South Asia: the hydrological background, Hydrol. Sci. J., 56, 775-788, https://doi.org/10.1080/02626667.2011.587425, 2011.

Tripathi, M. P.: Development of geographic knowledge in ancient India, Varanasi: Bharatiya Vidya Prakashan, Varanasi, 1969.

Verma, N. M. P.: Irrigation in India: Themes on Development, Planning, Performance and Management, M.D. Publications Pvt. Ltd., New Delhi, 1993.
Vuorinen, H. S., Juuti, P. S., and Katko, T. S.: History of water and health from ancient civilizations to modern times, Water Supply, 7, 49-57, https://doi.org/10.2166/ws.2007.006, 2007.

Weber, S. A.: Plants And Harappan Subsistence: An Example Of Stability And Change From Rojdi, Oxford \& IBH Publishing, New Delhi, 1991.

Wittfogel, K. A.: Developmental aspects of hydraulic societies, in: Irrigation Civilizations: A Comparative Study, pp. 43-57, Pan American Union, Washington DC. available at: http://www. columbia.edu/itc/anthropology/v3922/pdfs/wittfogel.pdf, 1955.

Webster, C.: The Sewers of Mohenjo-Daro, J. Water Pollut. Control Fed., 34, 116-123, available at: https://www.jstor.org/stable/ 25034575 (last access: 27 April 2020), 1962.

Witzel, M.: On the localisation of Vedic texts and schools (Materials on Vedic sakhas, 7), in: Ancient world. History, Trade and Culture before A.D. 650, professor P.H.L. Eggermont jubilee volume, edited by: G. Pollet, Department Oriëntalistiek, Leuven, 25, pp. 173-213, 1987.

Witzel, M.: Aryan and non-Aryan Names in Vedic India: Data for the linguistic situation, c. 1900-500 B.C., in: Aryans and NonNon-Aryans, Evidence, Interpretation and Ideology, edited by: J. Bronkhorst and M. Deshpande, Manohar Publishers and Distributors, New Delhi, pp. 337-404, 1999.

Witzel, M.: Central Asian roots and acculturation in South Asia: linguistic and archaeological evidence from Western Central Asia, the Hindukush and northwestern South Asia for early IndoAryan language and religion, in: Liguistics, archaeology and the human past, edited by: Osada, T., Manohar Publishers and Distributors, New Delhi, pp. 87-211, 2014.

Wolfe, P.: History of wastewater: World of water 2000 - the past, present and future. Water World, Water Wastewater Int. Suppl. Penn Well Mag. Tulsa OH, USA, 1999.

Water Resources Department, Government of Bihar: A National Consultation on Climate Resilient Water Resources: Development and Management, Water Resources Department, Government of Bihar, Sinchai Bhawan, Patna 800015, India, available at: http://wrd.bih.nic.in/download/year_2020/letter_0167_m.pdf (last access: 23 August 2020), 2020.

Wright, R. P.: The Ancient Indus: Urbanism, Economy and Society in South Asia, Cambridge University Press, London, available at: https://nyuscholars.nyu.edu/en/publications/ the-ancient-indus-urbanism-economy-and-society-in-south-asia (last access: 27 April 2020), 2010.

Yadav, A. L.: Some materials for the study of agriculture in Vedic India: Problems and Perspectives, in: History of Agriculture in India (upto c.1200 AD), 5, pp. 235-244, Centre for Studies in Civilizations, Delhi, India, 2008.

Yannopoulos, S. I., Lyberatos, G., Theodossiou, N., Li, W., Valipour, M., Tamburrino, A., and Angelakis, A. N.: Evolution of Water Lifting Devices (Pumps) over the Centuries Worldwide, Water, 7, 5031-5060, https://doi.org/10.3390/w7095031, 2015. 